\title{
Correction to: Creep Property and Phase Stability of Sulfur-Doped Ni-Base Single-Crystal Superalloys and Effectiveness of $\mathrm{CaO}$ Desulfurization
}

\begin{abstract}
SATOSHI UTADA, YUICHIRO JOH, MAKOTO OSAWA, TADAHARU YOKOKAWA, TAKUYA SUGIYAMA, TOSHIHARU KOBAYASHI, KYOKO KAWAGISHI, SHINSUKE SUZUKI, and HIROSHI HARADA
\end{abstract}

https://doi.org/10.1007/s11661-018-4836-4

(C) The Minerals, Metals \& Materials Society and ASM International 2018

\section{Correction to:}

Metallurgical and Materials Transactions A https://doi.org/10.1007/s11661-018-4710-4

IN the original article there is an error in the vertical axis of Figure 16. Following is the corrected Figure 16:

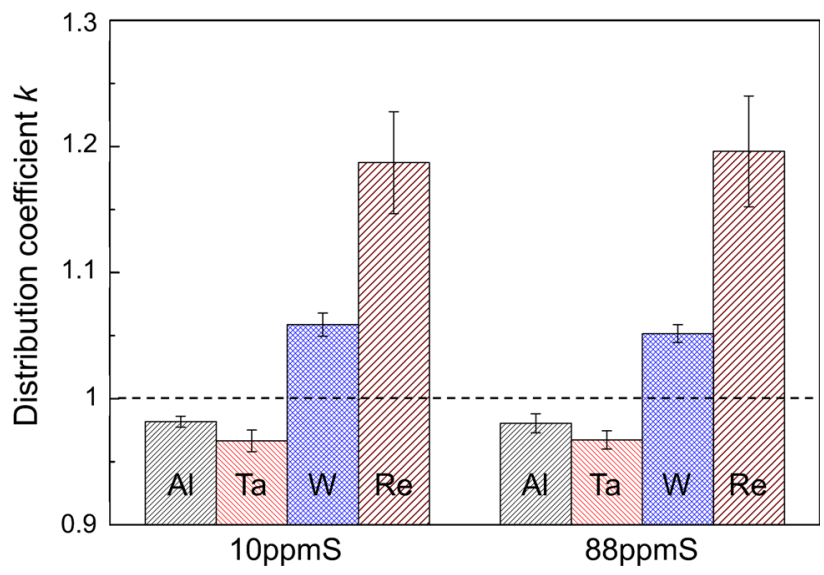

Fig. 16-Results of Scheil-type analysis on $10 \mathrm{ppmS}$ and $88 \mathrm{ppmS}$. The average fitted distribution coefficient of eight analyzed axes connecting the dendrite cores to the final solidification point is shown for $\mathrm{Al}, \mathrm{Ta}, \mathrm{W}$, and $\mathrm{Re}$ with error bars indicating standard deviation.
SATOSHI UTADA, YUICHIRO JOH, and TAKUYA SUGIYAMA are with Waseda University, Shinjuku, Tokyo 1698555, Japan, and also with the National Institute for Materials Science (NIMS), Tsukuba Science City, Ibaraki 305-0047, Japan. Contact email: utada.satoshi@ensma.fr MAKOTO OSAWA, TADAHARU YOKOKAWA, TOSHIHARU KOBAYASHI, KYOKO KAWAGISHI, and HIROSHI HARADA are with the National Institute for Materials Science (NIMS). SHINSUKE SUZUKI is with Waseda University.

The original article can be found online at https://doi.org/10.1007/ s11661-018-4710-4.

Article published online July 12, 2018 